\title{
Functional Brain Mapping in Humans
}

\author{
Akio Ikeda, M.D., Ph.D. ${ }^{1)}$ \\ 1) Department of Neurology, Kyoto University School of Medicine
}

Historically, there have been two main streams to detect the abnormality of the central nervous system and brain mapping, i.e., function such as EEG since 1929 vs. morphology such as CT/MRI mainly since the late 70s. Both are essential and complement each other, and the neurosurgical approach has helped develop these clinical methods. Since the old era of 19th century, lesion study and seizure semiology study have provided us with the most important, fundamental knowledge of functional mapping of the cerebral cortices. Lesion study provides the information of chronic state of the brain pathology where compensatory mechanisms are already developed, whereas seizure semiology study only provides transient change of brain function without compensatory mechanisms, and thus the two methods may ultimately produce different results. Similarly, recently well established methods, namely 1) direct cortical stimulation and 2) activation studies by means of EEG/MEG (evoked potentials, event-related potentials and the equivalent magnetic field), cerebral blood flow (functional MRI) or receptor imaging (PET, SPECT), also provide similar features with regard to the compensatory mechanism. As for human brain mapping, delineation of the pre-supplementary motor area (SMA) and SMA proper, mapping of the higher cortical function such as language, praxis and will, out-of body-experience, and ictal apraxia will be discussed. In summary, clinically, brain mapping method with the information of the degree of compensatory mechanism will be expected and cortical mapping should always be interpreted with its own sensitivity and specificity.

(Received December 26, 2012 ; accepted January 16, 2013)

Key words : cerebral cortex, functional localization, cortical electric stimulation, cerebral functional imaging Jpn J Neurosurg（Tokyo）22:170-177, 2013

\section{はじめに}

本誌の「機能外科と神経科学」の特集で，「ヒトの大脳 機能局在」を概説するにあたり，ヒトの脳機能局在の検 索方法の発展には, 脳外科的ニーズと脳外科的手法の両 者が大きな原動力になっていることは明白であり，それ ゆえ「ヒトの大脳機能局在」においては, 単に mapping そのものにとどまるだけでなく, 代償機転を予想・考慮 した大脳機能局在が期待されることを最初に明記した
い. 本稿では, 主に臨床神経生理学・臨床神経学の立場 から, 発展の経緯, 大脳皮質の機能局在の検索方法とそ の特徴, 最近の話題・重要な点・見落としがちな点など を概説する。なお，本稿は，過去の筆者の総説 ${ }^{14)}$ と同じ テーマであるが，本稿ではその後の発展とより重要な点 を選択して強調した。

連絡先：池田昭夫, $\bar{\top} 606-8397$ 京都市左京区聖護院川原町 54 京都大学医学研究科脳病態生理学講座臨床神経学 Address reprint requests to: Akio Ikeda, M.D., Ph.D., Department of Neurology, Kyoto University School of Medicine, 54 ShogoinKawaracho, Sakyo-ku, Kyoto-shi, Kyoto 606-8397, Japan 


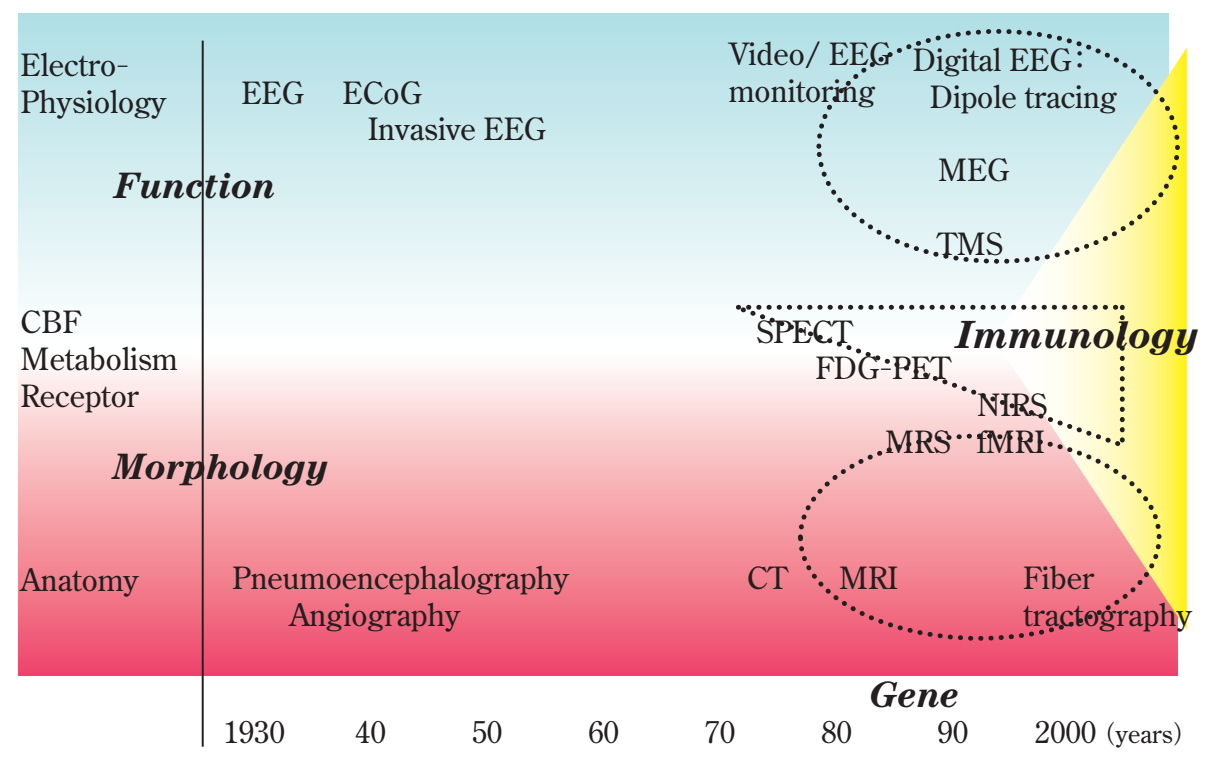

Fig. 1 Historical profiles of clinical methods used to investigate abnormalities of the central nervous system (such as epilepsy) and brain mapping

Two main streams, i.e., "function" such as EEG since 1929 and "morphology" such as CT/MRI mainly since late 70s, are both essential and complement each other. Furthermore, "gene" and "immunology" are also closely linked, and especially the latter becomes abnormal before abnormality in "function" and "morphology".

EEG: electroencephalography, ECoG: electrocorticography, MEG: magnetoencephalography, TMS : transcranial magnetic stimulation, SPECT: single photon computed tomography, PET: positron emission tomography, NIRS : near infrared spectroscopy, MRS: magnetic resonance spectroscopy, fMRI: functional MRI, CT : computed tomography, CBF : cerebral blood flow

(Cited from ref. 20)

\section{発展の経緯：脳外科手術が近代的機能局在の 手法の源動力となり,「機能」と「形態」の 2 基軸が相補的に発展してきた}

近代的な大脳機能局在は，19 世紀後半からの Jackson (内科医), Broca（脳外科医）によるヒトのてんかん発作 と脳機能局在の関連, 局在病変と脳機能局在の関連が注 目された. Pavlovにより, 条件反射が学習に伴うより複 雑な行為で大脸皮質内に獲得維持されることが明らかに された. 特にヒトの脳機能 mapping は, 1874 年米国シン シナチー市の脳外科医 Bartholow によって最初になされ た. その後, Ranson (1892), Cushing (1909), Foerster (1936), Penfield（1937）らによって脳外科手術の患者の 大脳皮質の電気刺激の結果より，哺乳類での大脳機能局 在はきわめて類似していることが明らかにされていっ た。これらをまとめて, 1950 年に The cerebral cortex of man : a clinical study of localization of function ${ }^{19)}$ が, 次い で 1954 年に Epilepsy and the functional anatomy of the human brain ${ }^{20)}$ が相次いで発刊された。
その中で前者の第 1 章では, 臨床的立場からの大脳機 能局在の研究への貢献は, 歴史的に 2 通りの方法があっ たと記されている。一つは，病態により局所性病変がも たらす症状を分析することで，こ扎は通常単純な機能消 失につながる (lesion study)。もう一つは部分てんかん 発作の症状とその進展様式を分析すること（seizure semiology study）で，これは皮質の自発的な一過性の機 能活性化が起こる，と記載されている20).

一方，臨床的な脳機能検索法の進歩の概要をまとめた ものが Fig. 1 である ${ }^{14)}$. 中枢神経系の機能検索方法には, 大きく分けて「機能」と「形態」の 2 方法があり，前者 の基軸は 1929 年に世界で初めて発表されたヒトの脳波 とその臨床応用であり ${ }^{2)}$, 電気生理学的方法として, 脳 磁図，デジタル脳波，磁気刺激などが進展した。脳の非 侵襲的形態検査は，脳波に比較して立ち後れ，当初は気 脳写，脳血管撮影しかなく，頭部 CT が 1970 年代, MRI が 1980 年代に臨床で使用されるようなった。また核医 学的手法においては，とりわけ 1990 年代前半までは $\mathrm{H}_{2} \mathrm{O}^{15}$ を用いた PET での課題負荷試験で局所脳血流変化 
Table 1 Clinical methods for human brain mapping

1 ) Methods related to clinical situation

a) Lesion study (intracerebral lesions vs. symptoms)

b) Seizure semiology study

2 ) Modern, sophisticated methods for brain mapping

a) Cortical mapping by means of electric- and magnetic stimulation (extrinsic brain activation methods)

b) Intrinsic brain activation (steady state activation)

b-1) Cortical generators of evoked potentials (magnetic fields), event-related potentials (magnetic fields), and high frequency oscillation (HFO)

b-2) Regional cerebral blood flow analysis (functional MRI, PET, SPECT, etc.)

から大脳機能 mapping を進める方法が主体であった。 そ の後 1993 年に functional MRI の手法が開発され, 外部か らの放射性トレーサーを用いずに, 局所脳血流の増加を deoxy-Hb の変化から計測する画期的な手法が実用化さ れた。

2000 年代になり, MRI での fiber tractography による 皮質間の連結を画像化する方法も実用化されてきた。ま た機能検査の基軸である頭皮上脳波を上述した functional MRI と同時記録することにより，脳波変化に相当 する事象に伴う局所脳血流変化を脳表面だけでなく，皮 質下構造での変化をも可視化することが可能となってき た.

\section{大脳機能局在の検索方法 : 各方法の感度 （鋭敏度）と特異度を念頭に置き， 代償機転の関与などを常に考慮する}

上述の大脳機能 mapping の進歩と, 脳機能検索法の進 歩をまとめると, 臨床的には, 大脳機能局在の検索方法 は, Table 1 に示すように，1）病態との関連による臨床 的手法，2）近代的検索方法に大きく分けることができ る. 1）は, 現代的な手法が発達する前の 19 世紀以降に 臨床の場において病態研究の中で臨床的知見に基づいて 培われてきた臨床的趴智といえるもので，さらにa） lesion study: 脳内病変と症状との関連, b) seizure semiology study：てんかん発作の症候分析，に分けることがで きる．2）は近代的な脳機能検索法として発展してきた 脳科学的手法であり, a）大脳皮質の電気・磁気刺激法 (外的脳刺激方法) と, b) 脳機能賦活検索法（常態での 賦活領域の検索）に分けることができる.

概して，検索方法には，1）すべからく感度（鋭敏度） と特異度があり，2）また大脳機能の症状を対象とする 場合はそれが急性の症状なのか, 慢性期の病態に伴う症 状であれば反対側あるいは周辺部位による代償機能が働
いた状態なのかで, 意義が大きく変わってくる．3）さ らに，ある手法で大脳機能局在が同定できた場合，その 部位が障害された時に実際に症状が出現するのか，一過 性の症状で回復するか, 永続的な障害をもたらすのか, などは, 次のステップの臨床的にむしろ重要な課題と なってくる，以上の点を考慮しつつ, Table 1 に記した代 表的な検索方法について最初に概説する。

\section{Lesion study（脳内病変と症状との関連)：慢 性期の代償機転後の症状を反映する}

本方法は急性期症状の分析にとどまらず慢性期の神経 心理学的症状の意義づけに重要な情報をもたらしてき た。逆に急性期を過ぎて安定した症状と病変との関連か らもたらされる情報は, 脳内の多彩な代償機転がすでに 賦活された後の病態を反映するととらえることができ る.そのため, 重要なことは, 局所脳代謝や脳血流変化 などによる健常者での脳機能 mapping あるいは皮質電 気刺激での mapping の結果と一部解離することがある ことである.たとえば，優位半球前頭葉の $1 \mathrm{~cm}^{2}$ のイ ズの脳表を電気刺激した場合, Broadmann 44 野とその近 傍の機能野であれば陰性運動反応 (negative motor response：NMR）（電気刺激中に, 意識は保持されている が随意的な持続筋収縮あるいは連続した随意運動が遂行 できなくなる）などの症状がもたらされる(101017)。しか し同領域の慢性期病変の症状のうち運動に関しては肢節 運動失行であり, 運動䘫失にはならない.

\section{Seizure semiology study（てんかん発作の症 候分析): てんかん発作の症状は正常機能の 3 変化 (刺激, 脱落, 変容)}

「熱力学が蒸気機関によって飛躍的に発展したように, てんかん学は神経科学に重要な役割を果たしてきた」と かつて 20 世紀にてんかん学が評された。てんかん発作 は大脳皮質の神経細胞群が突発的に脱分極して過剩な興 
Table 2 Comparison of symptoms among epileptic interference, activation and inactivation (or inhibition)

\begin{tabular}{|c|c|c|c|}
\hline Cortical areas & Interference & Activation & Inactivation（or Inhibition） \\
\hline $\begin{array}{l}\text { MI } \\
\text { SI } \\
\text { primary visual area } \\
\text { auditory cortices }\end{array}$ & & $\begin{array}{l}\text { convulsion, myoclonus } \\
\text { hyperesthesia } \\
\text { elementary visual hallucination } \\
\text { tinnitus, auditory hallucination }\end{array}$ & $\begin{array}{l}\text { paralysis, negative myoclonus } \\
\text { sensory defects } \\
\text { scotoma } \\
\text { deafness }\end{array}$ \\
\hline $\begin{array}{l}\text { SMA proper } \\
\text { SII } \\
\text { frontal eye field }\end{array}$ & & $\begin{array}{l}\text { tonic convulsion } \\
\text { pain, hyperesthesia } \\
\text { contralateral version }\end{array}$ & proximal weakness \\
\hline $\begin{array}{l}\text { speech area } \\
\text { SNMA (pre-SMA) } \\
\text { PNMA (Brodmann's 44) }\end{array}$ & $\begin{array}{l}\text { aphasia } \\
\text { NMS } \\
\text { NMS }\end{array}$ & (negative myoclonus) & \\
\hline
\end{tabular}

MI : primary motor area, SI : primary somatosensory cortex, SMA : supplementary motor area, SII : second sensory area

SNMA : supplementary negative motor area, PNMA : primary negative motor area

NMS : negative motor seizure

(Modified from ref. 12)

奮をもたらすことで, 神経学的には陽性症状 (刺激症状) をもたらすことが多く, 特に一次感覚運動野では単純な 刺激症状として，痤攣，しびれ感，あるいは視覚・聴覚 の陽性症状が起こる (epileptic activation $)^{20)}$ 。一方, 皮質 の神経細胞群が脱分極することで本来の脳機能そのもの が抑制 (epileptic inhibition)（=不活性化 inactivation）あ るいは干渉 (epileptic interference) されて, 陰性症状 （機能低下症状）をもたらすこともある20). epileptic inhibition の例としては, 発作時麻痺, 陰性ミオクローヌス, 視野欠損, 聴覚低下, 感覚鈍麻などがある. epileptic interference は高次の大脳領野で本来の高次脳機能が干渉さ れて低下する場合が多く, 発作時失語, 陰性運動発作 (発作時運動制止) などが挙げられる $(\text { Table } 2)^{13)}$ 。これ 以外に, 干渉により本来の正常高次脳機能が変容して出 現することもあり, たとえば déjà vu (既視感)・ jamais vu (未視感) は, 親近感（familiality）が発作性に変化する ことであるが, 本来の海馬と扁桃体の有する記憶と情動 機能が，一部変容して刺激症状として出現したものとと らえられる。

このように, てんかん発作の症状は, 正常脳機能を介 して初めて発現する, 正常機能の 3 変化（刺激, 脱落, 変容）といえる（Fig. 2)。しかもそれが，一過性・超急 性期の症状として発現しており, 上記の慢性期の脳内病 変による症状分析でみられる「慢性期の代償機転後の症 状」ではないことはきわめて重要である.
3 大脳皮質の電気・磁気刺激法: 外的刺激に よっててんかん発作と類似の状態を脳機能に もたらすことができる画期的な方法である

皮質電気刺激は, 最も確実な大脳機能マッピング法で ある。運動野あるいは一次感覚野は, 単発刺激で誘発反 応（単発の筋収縮，感覚症状）を検索することもできる が，通常は高頻度電気刺激 $(1 \mathrm{~cm}$ 間隔で脳表に装着した 直径 $3 \mathrm{~mm}$ の硬膜下電極間を $50 \mathrm{~Hz}, 0.2 \mathrm{msec}$ の持続時 間の極性交互の矩形波で 1 $15 \mathrm{~mA}$ の範疇) で刺激する.

刺激の最中には刺激電極およびその近傍の電極から持 続して脳波を記録して, 後発射あるいは脳波上の seizure pattern が誘発されていないか確認する必要がある. 陽性感覚反応の誘発 (一次感覚野, 二次感覚野), 陽性運 動反応の誘発 (一次運動野, 補足運動野), 陰性運動反応 (negative motor response) の誘発9)，失語症状（通常は まず刺激中に音読の障害が出現するかどうかでスクリー ニングされる）(言語野）などが同定される.特に高次脳 機能の検索には，5秒以上の刺激時間を要することもあ る.さらに症例によっては, Gerstmann 症候群の可能性 が考えられる優位半球の頭頂葉では，失書，失算，手指 失認, 左右失認の検索を行う場合もある ${ }^{18)}$.

皮質電気刺激には，以下の問題点が列挙される。a）刺 激電極あるいはその近傍にてんかん原性焦点が存在する 場合，発作誘発の危険を伴う。またそのために十分に刺 激強度を上げられない場合があり, 真に刺激電極直下の 皮質機能が陰性か陽性か確認できないことがある. b) 適 切な刺激強度では, 電極直下の皮質にきわめて限局して 電流密度が高くなるため, 刺激効果は電極に直接接した 皮質（脳冠部分）のみしか検索できない. 一方脳溝内の 
Ictal symptoms could represent 3 changes of normal cortical functions, i.e., activation, inhibition, and distortion.

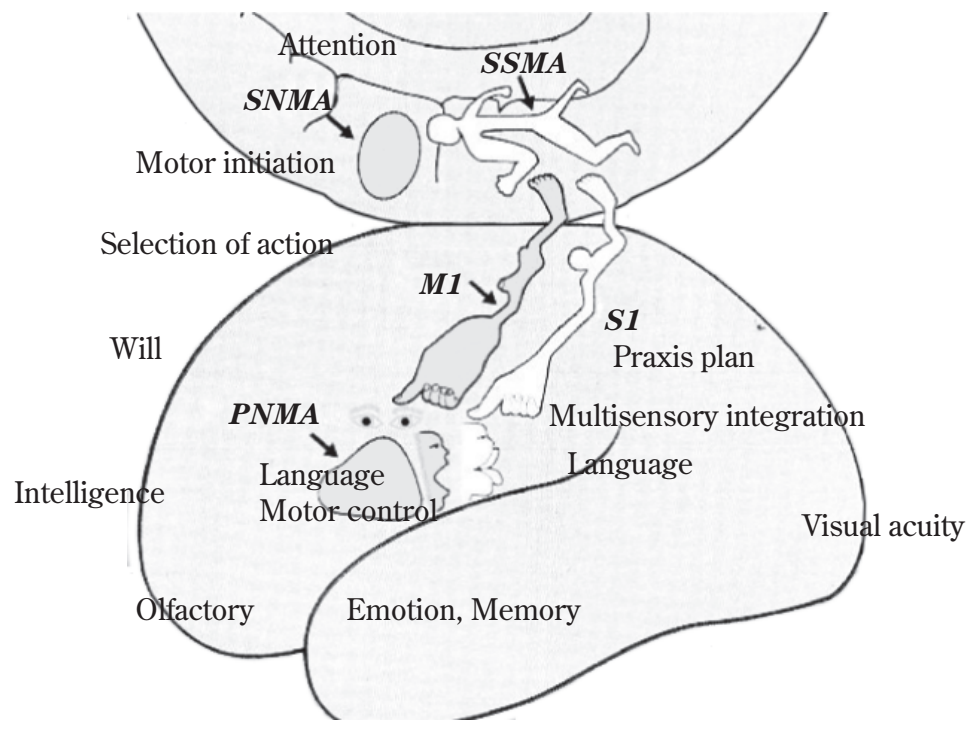

Fig. 2 Schema of functional localization in human cortices for understanding epileptic seizure semiology

皮質は，硬膜下電極を脳溝内に留置しないため電気刺激 検索が実際はなされないことになる.c)小児の場合は, 電 気刺激に対する皮質の興奮性が成人と異なるために，成 人で設定された刺激上限でも陽性反応が表れないこと （偽陰性）が少なからずある。d）また一方，電気刺激の 周囲への伝播などの影響により偽陽性所見も示し得る。

\section{4 各種脳機能検索法：人工的な脳刺激などでは なく, 生理的な常態での脳賦活領域を検索でき}

\section{る}

上述した大脳の直接の電気・磁気刺激は，いわば人工 的な状態であり，また電気刺激がてんかん発作を限りな く模倣した状態とすれば一種の病的状態で脳機能 mapping がもたらされたものといえる。一方, Table 1 に示さ れた近代的な各種脳機能検索法は, 生理的な感覚刺激, 運動負荷，心理的課題などによって生理的に脳機能が賦 活された状態を, 脳電位, 血流の微細な変動としてとら えることで可視化している.正常に賦活される領域には, 重要で中核的な領域だけでなく, 二次的に賦活される(余 剩あるいは代償機転に関連するような）領域をも同時に 含まれていることが少なくない.すなわち, Table 1 の古 典的な検索方法のうち, lesion study で記したように慢性 期の代償機転後の状態を反映している部分も，同時に賦 活化して可視化していることが容易に理解できる.

\section{1. 誘発電位磁場・事象関連電位磁場, 高周波律動の 発生源検索}

各種の感覚誘発電位 (体性感覚誘発電位 SEPs, 聴覚誘 発電位 AEPs, 視覚誘発電位 VEPs 等) を直接硬膜下電 極から記録することは，それぞれの一次感覚野の同定に きわめて有用である。同様に頭皮上記録の誘発電位ある いは脳磁場変動の発生源を同定する方法も大脳機能 mapping には重要な情報を提供する ${ }^{8) 12) 16)}$. 一次感覚野以 外にも, 二次感覚野あるいは補足運動野からの SEPs の 記録もなされており，機能同定に有用である。詳細は， 別途総説を参照されたい ${ }^{14)}$. 一方， $100 \mathrm{msec}$ 以上の潜時 の誘発電位の中で, 感覚刺激の椂式によらない内因性脳 活動の変化を反映するものは事象関連電位 (eventrelated potentials）と呼ばれ，1960 年代から高次脳機能 (準備，期待，判断，言語，注意など）とその局在同定の 研究が進められてきた。その中で, 運動野の機能 mapping には，事象関連電位の一つである運動準備電位が臨 床応用されている。特にてんかん外科の術前機能 mapping では，電気刺激と異なり，a）痤攣発作を誘発せず 安全，b）同時に 50〜100 電極といった多数の電極を検 索できる，c）検索したい随意運動を対象にできる，な ど，高頻度皮質電気刺激による運動 mapping の問題点を 解決できることが注目に值する7).

上記の誘発電位磁場・事象関連電位磁場は，加算平均 により $\mathrm{S} / \mathrm{N}$ 比を改善して反応波形を同定抽出してその 


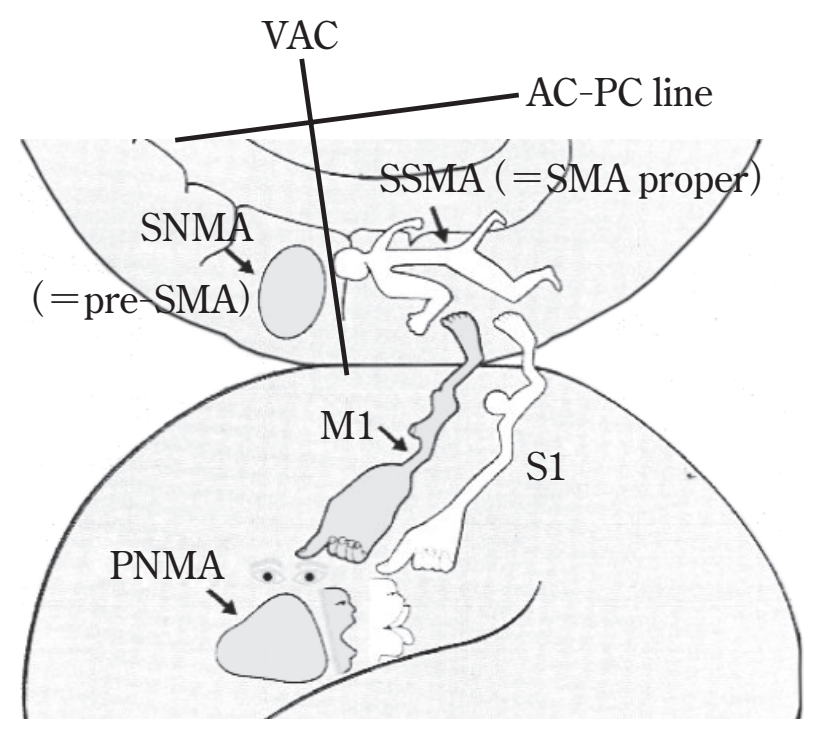

Fig. 3 Schema of localization of supplementary motor area (SMA) proper and preSMA in human mesial frontal cortices

Currently, the human SMA is divided into the rostral- (pre-SMA) and caudal (SMA proper) parts by the VAC line. The SMA proper has its own somatotopy as MI, and the foot area of the SMA proper often extends into the lower part of the paracentral lobule.

The SNMA and PNMA manifest negative motor response via high frequency cortical stimulation as described in the text, and both roughly correspond to Broadman's area 44 and pre-SMA, respectively.

VAC: a line on the anterior commissure perpendicular to the $\mathrm{AC}-\mathrm{PC}$ line, SNMA: supplementary negative motor area, PNMA: primary negative motor area, SSMA: supplementary sensorimotor area, MI: primary motor area, S1: primary somatosensory area.

(Cited from ref. 15)

発生源を検索してきた，近年の機器の発達により，生体 信号を多チャンネルから同時に非常に広い周波数帯域か ら記録することが容易となり，特に $50 \sim 100 \mathrm{~Hz}$ あるい はそれ以上の周波数の高周波律動（high frequency oscillation：HFO）を，単一試行で同定することが可能となっ てきた。特に，言語，運動感覚野，記憶などの機能に関 連する領域を検索することが可能となりつつある。また 高周波律動が運動感覚野さらには言語野の mapping に 有用であることが最近指摘されている(4)5).

\section{2. 局所脳血流変化の検索 (Functional MRI, PET, SPECT 等)}

局所脳血流の増加により流入する oxy-Hb によって deoxy-Hb が相対的に減少して MRI 信号が相対的に増 強することを画像化する手法が実用化されて以来，非侵 襲的に大脳機能局在を mapping できる手法として注目
されている。

\section{臨床的な大脳機能局在の話題}

\section{1 前補足運動野と固有補足運動野}

Fig. 3 $^{15)}$ に示すように, 1949 年に Penfield と Welch が ヒトの下肢の一次運動野の前方領域での内側前頭葉で, 電気刺激によって「肩上腕の運動，両側の体幹の」運動 反応が誘発された領域を補足運動野（supplementary motor area：SMA）という呼称で記載した. Sir John Eccles は 1981 年に「すべての随意運動においては，最 初の神経活動は専ら両側の SMA に起こる」という仮説 を提唱するに至った。その後の研究で, 補足運動野は前 方の「前補足運動野」（pre-SAM）（6a $\beta ）$ と「固有補足 運動野」(SMA propper）（6a $\alpha ） に$ 分かれ，それぞれ随意 運動の高位の発現中枢の役割と，記憶に基づく随意運動 遂行とその補足的な役割（運動前に先行した体幹・四肢 近位部の姿勢制御）を担っていることが明らかにされて きた。固有補足運動野自体にも体性機能局在（somatotopy）があり，後方は傍中心小葉（paracentral lobule）の 下半分に及ぶこともある ${ }^{6)}$. 今後臨床症状との相関の検 討が進められることが期待される11).

\section{2 ミラーニューロンシステム}

Broadmann 44 野は, 古典的には Broca 野に相当して言 語中枢とみなされてきたが，サルの研究で他人の運動の 観察，理解，模倣，学習にかかわることが示され，ヒト でも同領域を中心に運動関連領域に広く分布することが 示唆された. 臨床的には自閉症, 運動回復のリハビリテー ション，失行の一つである反響動作（echopraxia）との 関連が注目されている21).

\section{3 高次脑機能局在}

高頻度電気刺激で大脳機能局在を検索する際には, p 172-2で記したような発作時抑制（epileptic inhibition） あるいは干渉（epileptic interference）と同様に，高頻度 電気刺激で本来の脳機能活動が抑制・干渉されて，高次 脳機能が脱落症状として出現することによる失語, 麻痺, 運動制止, Gerstmann 症候群の症候18)などが報告されて いる。しかしながらその感度は高くなく，上述した高周 波律動（HFO）の解析は，単一試行で可能なことなど， 今後飛躍的に発展する可能性がある.

\section{4 感覚統合}

体外離脱体験 (out-of-body-experience) は, temporopa- 
rietal junction である角回や角回前方・上側頭回後方を 含む側頭葉・頭頂葉境界領域に本症候の責任領域が推定 されている，同部位における，触覚，視覚および前庭感 覚の統合は, 運動や感覚を介した身体内空間 (personal space）の統合と, 身体外空間（extrapersonal space）で の位置の統合に欠かせない。この統合障害が身体内空間 と身体外空間の解離を引き起こし, 本症状が出現する原 因の一つと考元られている ${ }^{322)}$. さらにこの左領域の電 気刺激では, 後方に影のようにヒトが潜んでいるょうに 感じる幻覚が誘発されることも指摘されている1).

\section{Ictal apraxia}

Broadmann 44 野あるいは pre-SMA 領域を高頻度で 5 秒間電気刺激すると, 上述したように, 陰性運動反応 (negative motor response：NMR）（電気刺激中に, 意識は 保持されているが随意的な持続筋収縮あるいは連続した 随意運動が遂行できなくなる）が出現する。これが麻痺 （paresis）か失行（apraxia）かは議論の余地がある.

一般的に apraxia は, lesion study における症候学とし て記載されてきた慢性の病態であり, 少なくともある程 度以上の代償的機転が脳内ネットワークですでにもたら された後の状況である，短時間の高頻度皮質電気刺激に よる超急性の誘発症状は, たと元同じ脳内構造と機転が 関連していても慢性期の症状とは異なると予想される.

同様にてんかん発作中に意識はありながら発作時に体 の一部が動かせなくなる症状 (negative motor seizure) が まれながらあり，NMRにきわめて類似する ${ }^{18)}$ 。その発 作型を記載するには，「ictal apraxia」という用語が妥当 か否かは議論の余地がある ${ }^{18)}$. 加えて, 電気刺激自体で も, 慢性の病態と考えられる ideomotor apraxia が下頭頂 小葉の電気刺激で出現することがあり ${ }^{23)}$, 単なる代償機 転の有無だけで, ideomotor apraxia か arrest of motion か の 2 分論ではなさそうである。

\section{おわりに}

以下の 2 点をまとめとしたい. 1) 大脳機能局在の検 索方法の違いにより, 機能局在の結果と解釈が異なる. 2）代償機転を予想・考慮した, 大脳機能局在の mapping が期待される。

\section{文 献}

1) Arzy S, Seeck M, Ortique S, Spinelli L, Blanke O: Induction of an illusory shadow person. Nature 443:287, 2006.
2) Berger $\mathrm{H}$ : Über das Elekrenkephalogramm des Menshen. Artch Psychiatr Nervenkr 87:527-570, 1929 (山口成良 訳：ヒトの脳波について [第 1 回, 第 2 回, 第 3 回]. 精神医学 23:829-838, 951-962, 1073-1081，1981).

3) Blanke O, Ortigue S, Landis T, Seeck M: Stimulating illusory own-body perceptions. Nature 419:269-270, 2002.

4) Buzsáki G, Silva FL: High frequency oscillations in the intact brain. Prog Neurobiol 98: 241-249, 2012.

5) Crone NE, Korzeniewska A, Sinai A, Franaszczuk P: ERD/ERS and ERP. in Ikeda A, Inoue Y (eds) : Eventrelated potentials $(E R P S)$ in patients with epilepsy: from current state to future prospects, Progress in epileptic disorders. vol. 6, Paris, John Libbey, 2008, pp.214-246.

6) Ikeda A, Lüders HO, Burgess RC, Shibasaki H: Movement-related potentials recorded from supplementary and primary motor area: role of supplementary motor area in voluntary movements. Brain 115: 1017-1043, 1992.

7) Ikeda A, Shibasaki H: Intracranial recording of Bereitschaftspotentials in patients with epilepsy. in Jahanshai M, Mallett M (eds): The Bereitschaftspotentials : movement-related cortical potentials. New York, Kluwer Academic/Plenum, 1993, pp.45-59.

8) Ikeda A, Shibasaki H: Event-related evoked potentials to delineate eloquent cortex. in Rosenow F, Lüders HO (eds): Handbook of Clinical Neurophysiology: epilepsy. Amsterdam, Elsevier, 2004, pp.333-345.

9）池田昭夫：陰性運動野-1. 臨床脳波 48: 303-312, 2006.

10）池田昭夫：陰性運動野-2. 臨床脳波 48: 371-377, 2006.

11）池田昭夫：ヒトの随意運動における補足運動野の機能と 臨床的意義. 臨床神経 $47: 8-20,2007$.

12) Ikeda $A$, Shibasaki $H$ : Cortical mapping using evoked potentials and Bereitschaftspotentials. in Lüders HO(ed) : Textbook of epilepsy surgery. London, Informa UK Ltd, 2008, pp.1036-1048.

13) Ikeda $A$, Hirasawa K, Kinoshita M, Hitomi T, Matsumoto $\mathrm{R}$, Mitsueda T, Taki JY, Inouch M, Mikuni N, Hori T, Fukuyama H, Hashimoto N, Shibasaki H, Takahashi R: Negative motor seizure arising from negative motor area: is it ictal apraxia? Epilepsia 50:272-284, 2009.

14）池田昭夫：ヒトの大脳機能局在概説一機能局在研究の大 航海時代一. Clin Neurosci 28：1096-1103， 2010.

15) Lim SH, Dinner DS, Pillay PK, Lüders H, Morris HH, Klem G, Wyllie E, Awad IA: Functional anatomy of the human supplementary sensorimotor area: results of extraoperative electrical stimulation. Electroencephalogr Clin Neurophysiol 91: 179-193, 1994.

16) Lüders H, Dinner DS, Lesser RP, Morris HH: Evoked potentials in cortical localization. J Clin Neurophysiol 3: 75-84, 1986.

17) Lüders HO, Dinner DS, Morris HH, Willie E, Comair YG : Cortical electric stimulation in humans: the negative motor areas. in Fahn S, Hallett M, Lüders HO (eds) : Negative motor phenomena. Adv Neurol vol. 67, New York, Lippincott - Raven, 1995, pp. 115-129.

18) Morris HH, Lüders H, Lesser RP, Dinner DS, Hahn J: Transient neuropsychological abnormalities (including Gerstmann's syndrome) during cortical stimulation. Neurology 34:877-883, 1984.

19) Penfield W, Rasmussen $T:$ The cerebral cortex of man $: a$ clinical study of localization of function. New York, MacMillan Company, 1950.

20) Penfield W, Jasper H: Epilepsy and the functional anatomy 
of the human brain. Boston, Little, Brown, 1954.

21) Rizzolatti G, Fabbri-Destro M, Cattaneo L: Mirror neurons and their clinical relevance. Nat Clin Pract Neurol 5:24-34, 2009.

22）下竹昭寛, 松本理器, 池田昭夫. 頭頂葉てんかん, Clin
Neurosci 27: 452-454, 2009.

23）下竹昭寛, 松本理器, 國枝武治, 福山秀直, 三國信啓, 宮本享，高橋良輔，池田昭夫：行為関連ネットワークの 機能分化：皮質電気刺激による失行様症状の検討，臨床 神経生理学 40:446, 2012 (抄).

\section{要}

旨

ヒトの大脳機能局在

池田 昭夫

歴史的に, 中枢神経系の異常を検索する, あるいは脳機能 mapping のための臨床的検査方法には, 1929 年以降の脳波などの「機能」検査と, 主に 1970 年代以降の CT, MRI などの「形態」検査の 2 基軸があった，両者は基本的かつ相補的手法であり，脳外科臨床がこの 2 大手法を発展させてきた. 19 世紀以来, lesion study と seizure semiology study はこの流れの中で最も重要な基礎的臨床知見 をもたらした. lesion study は慢性期の代償機転が働いた状態での症状を示したが, seizure semiology study は，慢性期の代償機転がない状態の一過性の症状をもたらし，そのために両者は時に違う 結果を生じさせる. 同様に，1）大脳の直接電気刺激と，近年発展が目覚ましい，2） EEG/MEG・局 所脳血流・受容体イメージングを用いた大脳賦活化課題研究は, 同様の代償機転の関わりの有無を同 時に考慮する必要がある. ヒトの脳機能 mapping として, 補足運動野の新知見, 高次脳機能局在, 体外離脱体験，発作時失行について概説する，ヒトの脳機能 mapping においては, 代償機転の関わ りと, それぞれの感度と特異度を常に考慮する必要がある。 